\title{
The Red Syenite of the Pilanesberg Complex; a potential raw material source for the South African ceramics and glass industry
}

\author{
B. Pantshi and H.F.J. Theart \\ Department of Geology, University of Pretoria, Pretoria 0002, South Africa. \\ e-mail: bpantshi@telkomsa.net, htheart@srk.ac.za \\ (c) 2008 March Geological Society of South Africa
}

\begin{abstract}
The Red Syenite deposit on the farm Zandrivierspoort $210 \mathrm{JP}$, located on the periphery of the Pilanesberg Alkaline Complex, is considered here as a potential source of nepheline syenite, a material that is used as a flux in the manufacturing of glass and ceramics. Glass and ceramics manufacturers have different specifications as far as the quality and the product form is concerned. Local glass manufacturers generally require beneficiated material with a low Fe content, depending on the kind of glass being manufactured. Ceramics manufactures also require material with a low Fe content, but the material may be unbeneficiated as most of these factories already have facilities to remove Fe and other materials considered deleterious to the product or manufacturing process. The minimum requirement is that the material must be crushed and milled to a specific size fraction $(<10 \mathrm{~mm})$. A common concern expressed by the industry is the requirement for continuity of production, and an assurance of consistent quality from the supplying deposit. The availability of feldspar as an alternative starting material, at a lower cost than nepheline syenite, is responsible for an unwillingness of potential users to switch to nepheline syenite, despite its proven advantages.

Extensive additional geological confirmation is required to estimate the sized and quality of the resource of the nepheline syenite in the Pilanesberg Alkaline Complex. To demonstrate its viability, a preliminary investigation has been undertaken on one such a deposit to show that the deposit will probably be able to sustain production over a considerable period and display internal homogeneity that would ensure the consistent quality of the material produced. Given the uncertainties in all parameter considered at this stage it must be stressed that the financial study is merely used to highlight the projects potential viability and to identify its risks. For this purpose a hypothetical project was designed which shows that such an operation would be most sensitive to the production rate, capital required, and the selling price of the product. Transport and operating costs show a less significant influence on the viability of the project.
\end{abstract}

\section{Introduction}

The South African glass and ceramics industry are currently undergoing unprecedented growth. This has lead to a renewed interest in the raw materials required and has put a great strain on existing suppliers. Minnaar and Theart (2006) discussed the viability of feldspar that could be obtained from pegmatites within the western part of Namaqua Metamorphic Province as a potential source of such raw materials. In this paper the authors are going to examine the financial viability of a nepheline syenite deposit related to the Pilanebeg Complex, but which falls outside the national heritage area. The objective here is not to provide a bankable feasibility study but to demonstrate the fact that financial studies conducted at a very early stage can provide direct indications whether further work are justified or not. In addition, it may also expose inherent weaknesses of the project early on, that when addressed may contribute greatly to the future success of the project. The financial testing of geological exploration targets should therefore be regarded as an integral and very important component of exploration, encapsulated in the words of M.J. Knuckey, delivered at a SEG workshop in 1998, "Exploration is not a science it is business"

Nepheline syenite is a scarce igneous rock that resembles granite in texture; it consists mainly of nepheline and alkali feldspars. Nepheline-bearing rocks, although relatively rare are widespread throughout the world and deposits of nepheline syenite are common amongst these. Larger nepheline syenite intrusions are known in the United States (Texas, Arkansas and Massachusetts), Canada (Ontario, British Columbia), Brazil, Norway and the Russian Federation. They are also found in Bohemia and in several places in Sweden and Finland, South Africa, Madagascar, India, Mozambique and Tasmania. More than $90 \%$ of the nepheline syenite mined worldwide is used in manufacturing glass, ceramics, paint, and filler material (Daly, 1990). Size is an important criterion when considering potential operations, but more important are the purity and location of the deposit.

Deposits exploited in a larger scale are located in Canada, New Mexico, Norway, USSR and United States of America (USA). More than $60 \%$ of the global annual production is exported to the USA and about $20 \%$ to Canada. South African deposits are located in the KwaZulu-Natal (the Bulls Run Syenite Complex), the Northwest (within the Pilanesberg Akaline Complex, Figure 1) and the Gauteng Provinces (the Franspoort Intrusion). Their locations limit their viability, hence the existence of only one operating nepheline syenite quarry in South Africa, located just outside Pretoria, exploiting the Franspoort Syenite Intrusion. Feldspar is commonly used in South Africa as an alternative to nepheline syenite, for the main source of alkalis and alumina in glass manufacturing (Boelema, 2000). 


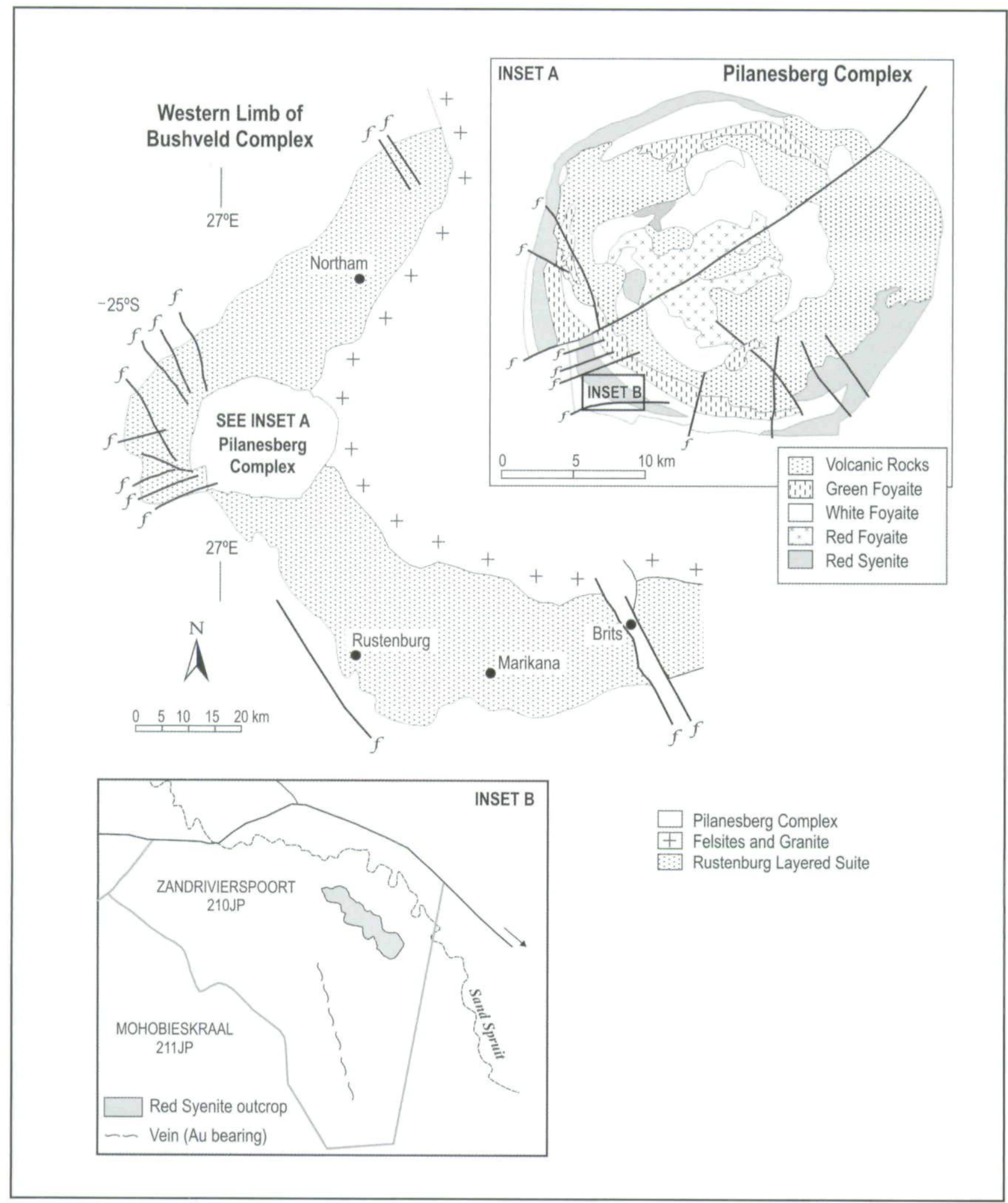

Figure 1. Location of the Pilanesberg Complex in the western limb of the Bushveld Complex (after Viljoen and Schürman, 1998; Schürman, 1998). Insert (A) Geology of the Pilanesberg Complex (after Lurie, 1986). Insert (B) The location of the Red Syenite outcrop on the farm Zandrivierspoort 210JP.

Nepheline syenite is rich in alkalis and alumina, which are contained in the feldspathoid and alkali feldspar minerals and the rock could therefore be used as a source of $\mathrm{Al}_{2} \mathrm{O}_{3}, \mathrm{Na}_{2} \mathrm{O}$, and/or $\mathrm{K}_{2} \mathrm{O}, \mathrm{SiO}_{2}$ in the manufacturing of various types of glass and ceramics. In glass and ceramics manufacturing, nepheline syenite, or feldspar, provides alkalis that act as a flux to lower the melting temperature of a glass or ceramics mixture. The ideal composition results in fast melting and fuel savings. In glass, nepheline syenite supplies alumina, which improves thermal endurance, increases chemical durability and resistance to scratching and breaking. A range of raw materials can be used (often interchangeably) in this manufacturing process. 


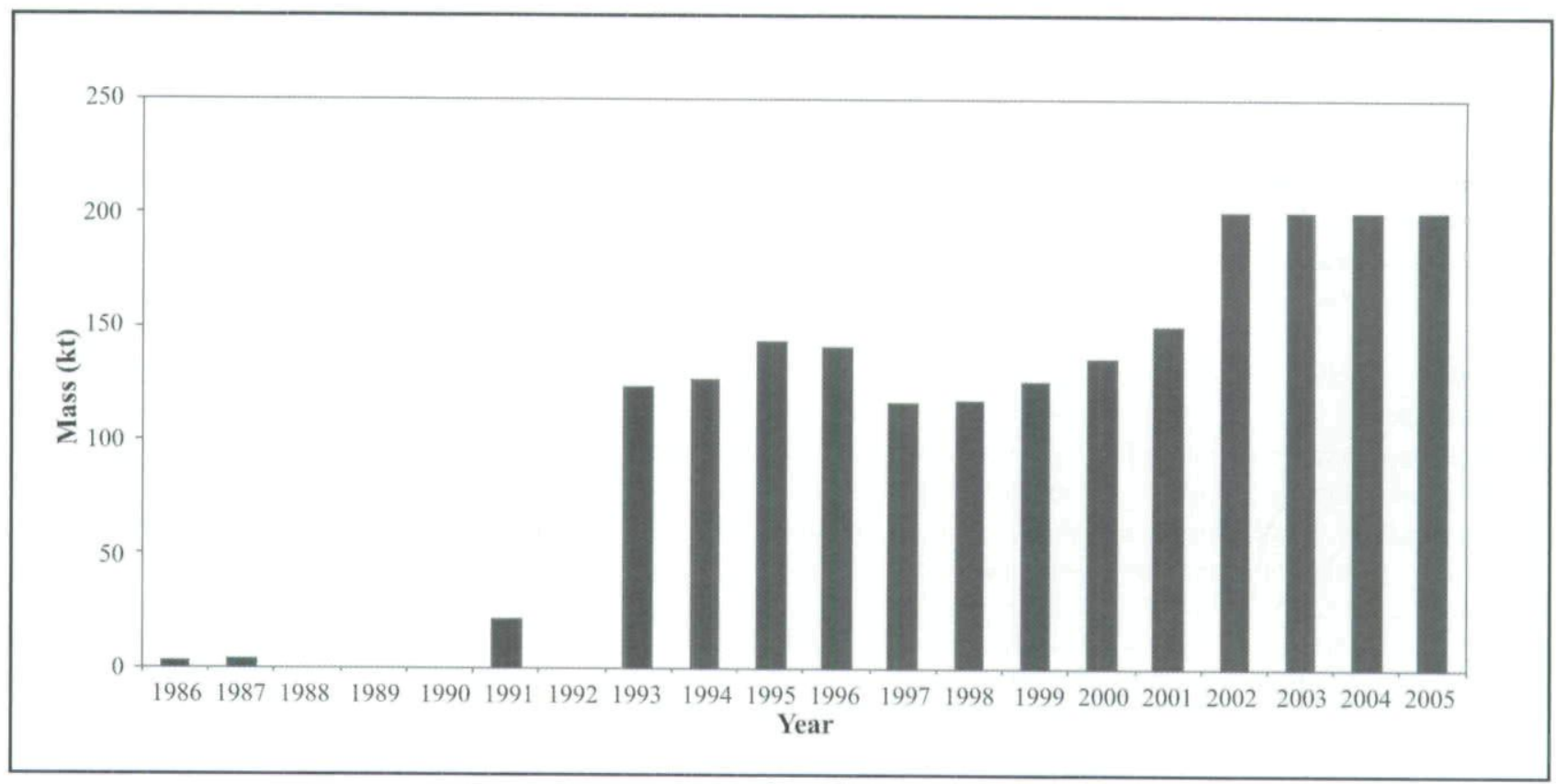

Figure 2. Documented sales of nepheline in South Africa (after Agnello et al., 2003, Agnello et al., 2004, and personal communication. Management of Mamelodi Quarries, 2006

The choice of raw material depends on the following considerations:

- Cost per ton

- Chemical consistency of material

- Uniformity and consistency of grain size

- Total iron content

- Levels of other impurities

- Stability and sustainability of supply.

In glass manufacturing, raw material used depends on the type of glass, cost per unit of alumina, and percentage of alumina. Ceramics manufacturers source the raw material based on the type of ceramic product to be manufactured, cost per unit alkali, percentage of alumina, percentage of total alkalis, $\mathrm{K}: \mathrm{Na}$ ratio, percentage of free silica, and colour on firing.

The nepheline syenite rock is crushed, milled and subjected to a series of magnetic separators in order to reduce the iron content by removing magnetite and other iron-bearing minerals. The characteristic size fraction and iron level of the product are modified to meet the specifications of individual customers as far as possible. The most important limiting factors in the exploitation of nepheline syenite in South Africa is the iron content, as seen in the percentage of dark minerals present, and the location of the deposit relative to its market. Location of the deposit is an issue for all industrial minerals as transport cost relative to the value of the product plays a very large role in considering the viability of it exploitation (Horn, 1994). The principal market in South Africa is located in the Gauteng Province.

The aim of this study is to investigate the viability of the Pilanesberg Red Syenite deposit (Figure 1) as a potential supplier of nepheline syenite for the Gauteng glass and ceramics market. The investigation entails issues such as the acceptability of the mineral product; the availability of sufficient resources to supply ceramics and glass manufacturers, quality compliance with South African product specifications, the potential demand for the product; the financial viability of exploiting the Red Syenite deposit, and risks associated with the project. Chemical analysis and limited metallurgical tests were conducted on a number of samples for this investigation. Selected manufacturers were requested to test the Pilanesberg Red Syenite raw material in their plants. The objective of the exercise was to ascertain if it is worth doing an in-depth study of the Pilanesberg deposit.

\section{Classification of nepheline syenite orebodies}

Nepheline syenite deposits are classified by the percentage of principal minerals present in the deposit, their colour, and by their origin (Minnes, 1975). A variety of names have been given to nepheline-bearing rocks, but the term "nepheline", as a commodity name, is often given to any rock containing 5 modal $\%$ or more of the mineral nepheline $\left[(\mathrm{Na}, \mathrm{K})\left(\mathrm{AlSiO}_{4}\right)\right]$. Commonly, the rock is of commercial interest when the nepheline content exceeds 20 modal \% (Minnes, 1975). Commercial nepheline syenite deposits and the products made from them are free of crystalline silica impurities (Cuillo et al., 2003). In North America, typical nepheline syenite ore consists of approximately 25 modal \% nepheline, 55 modal \% sodium feldspar, and 20 modal \% potassium feldspar.

Over the past few years, relatively small quantities of nepheline have been produced in South Africa, from a small operation called Mamelodi Quarries, near Pretoria. The product is locally used for glazing, aggregate and ceramics. The nepheline syenite from this quarry is sold 
beneficiated (R800/ton) or unbeneficiated (R400/ ton). For aggregate purposes a ton is sold at R40/ton. For the last 5 years, production has been on average 132, 000 and 65,000 tons for aggregate and ceramics respectively (personal communication, Production Manager, Mamelodi Quarries, 2006). Figure 2 shows sales of volumes of nepheline (nepheline syenite) produced in South Africa between 1986 and 2005.

\section{Suitability of nepheline syenite in ceramics manufacturing:}

The fluxing character of nepheline syenite is important in the production of ceramics. Most companies do a direct substitution of the material in their current body mix. Some of the tests generally conducted include:

- Standard Cone Fusion Test - to establish the fusion characteristics of the samples. This test is a function of particle size, particle size distribution, and chemical composition of the raw material.

- $\mathrm{pH}$ Test - this provides an indication of the presence and solubility of impurities.

- Other tests to evaluate the usefulness of the product include:

- Extraction characteristics

- Body separation

- Dry properties - shrinkage

- Fired properties - shrinkage.

Suitability of the Pilanesberg's Red syenite in glass manufacturing:

A local glass manufacturer tested this material with the fusion method, where a small fraction of nepheline syenite is substituted for feldspar, melted. The colour and appearance of the glass are then compared with those of a regular glass melt. The advantage of this test is that the effects of impurities not previously detected will be apparent on detailed inspection.

\section{Geology of the Pilanesberg Red Syenite Deposit.}

The Red Syenite deposit considered here belongs to the in the Pilanesberg Alkaline Complex (referred to as the Complex hereafter) with a poorly constrained age of $1250 \pm 60 \mathrm{Ma}$ (SACS 1980). It is located $50 \mathrm{~km}$ northnorth-west of Rustenburg, and $10 \mathrm{~km}$ south-west of SunCity (Figure 1, Insert B). It is situated on the farm Zandrivierspoort $210 \mathrm{JP}$, in the south-western quadrant of the complex (Figure 1, Insert A). The Pilanesberg region is well known as a conservation area, but the study area referred to here is located south of the boundary of the game reserve, although a part of the farm Zandrivierspoort $210 \mathrm{JP}$, located north of the Sandspruit riverbed is also part of the game reserve (Pilanesberg Expansion Phase One, 2005).

The Complex intruded the layered sequence of the western limb of the Bushveld Complex (Figure 1), extending $200 \mathrm{~km}$ along an arc from Thabazimbi to the north of Pretoria (Cawthorn, 2001). The Pilanesberg Complex is almost perfectly circular with an east-west diameter of $28 \mathrm{~km}$ and north-south diameter of $24 \mathrm{~km}$ (Figure 1, Insert A).

\section{Regional geology:}

Molengraaff (1906) recorded the presence Pilanesberg Complex for the first time in his map of the Transvaal, published in 1901 and in 1905. The first scientific descriptions of the nepheline-bearing rocks of the complex were provided by Brower, (1910) who studied the petrography of the rocks and was among the first to recognise the large scale circular structure of the Complex. Humphrey, (1914) and later Shand (1932) described the Complex's principal rock types. Shand (1932) identified the following major rock units in the Complex:

- A core of Red Foyaite, consisting mainly of microcline and altered nepheline known as liebenerite.

- The core of the Complex is succeeded by a complete ring of approximately 5 to $7.6 \mathrm{~km}$ wide White and Grey Foyaite, which consists of fresh nepheline and aegerine.

- There is also a green variety of foyaite, which occurs between the White Foyaite ring intrusions. The Green Foyaite differs slightly from the latter. In some areas the White Foyaite is covered by volcanic rocks.

- The Red Syenite forms a complete ring and represents outer wall of the Pilanesberg Complex in the south-east and north-west. On Zandrivierspoort the Red Syenite forms a prominent hill known as Burgwan's Kop.

Shand (1932) reported the following composition for the Red Syenite: 57.77 weight $\% \mathrm{SiO}_{2}, 18.08$ weight $\% \mathrm{Al}_{2} \mathrm{O}_{3}$, 0.78 weight $\% \mathrm{Fe}_{2} \mathrm{O}_{3}, 4.69$ weight $\% \mathrm{FeO}, 1.00$ weight $\%$ $\mathrm{MgO}, 2.27$ weight $\% \mathrm{CaO}, 5.53$ weight $\% \mathrm{Na}_{2} \mathrm{O}$, 5.26 weight $\% \mathrm{~K}_{2} \mathrm{O}, 0.22$ weight $\% \mathrm{MnO}$ and 0.21 weight $\% \mathrm{P}_{2} \mathrm{O}_{5}$.

The syenite has similar petrographic characteristics throughout the ring and is characterised by tabular crystals of feldspar, which vary in colour from pink to red (Retief 1963). The contact between the White Foyaite and Red Syenite is gradational. In some areas, dykes of foyaite cut the red syenite, making it clear that foyaite magma intruded later than the syenite. In addition to these rocks Shand (1932) also described various intrusive and extrusive volcanic rocks such as lava, tuffs and volcanic breccias and conglomerates belonging to the Complex.

The Red Syenite Deposit is compared in the following paragraphs with two other deposits for benchmarking purposes, the Table Mountain deposit in Canada and the Bulls Run deposit in Natal

\section{The Table Mountain Deposit}

This deposit is located at Table Mountain, Lincoln County, Oregon, Canada. Table Mountain forms a plateau, $822.96 \mathrm{~m}$ above sea level, in the Siuislaw 
National Forest. The deposit is estimated to contain measured resources of 26 million tons of recoverable nepheline syenite, out of an estimated resource of 525 million tons. The Table Mountain nepheline syenite has a Mohs scale hardness of 6 , a specific gravity of 2.57 and the unbeneficiated material contains: 59.62 weight $\% \mathrm{SiO}_{2}, 18.60$ weight $\% \mathrm{Al}_{2} \mathrm{O}_{3}$, and 2.86 weight $\% \mathrm{Fe}_{2} \mathrm{O}_{3}$.

Similar to the South African material, the utilisation of Table Mountain material in clear glass and ceramic items is limited by the high iron content and the run of mine material has to be beneficiated magnetically to remove some of the iron bearing minerals. The commercially beneficiated Grade A nepheline (product) contains: 60.04 weight $\% \mathrm{SiO}_{2}, 23.06$ weight $\% \mathrm{Al}_{2} \mathrm{O}_{3}$ and 0.08 weight $\% \mathrm{Fe}_{2} \mathrm{O}_{3}$. (Spectrum Canadian Nepheline Syenite, 2005).

\section{Bulls Run Syenite Complex:}

This complex is located in the Natal Thrust Belt, $180 \mathrm{~km}$ east northeast of Durban (Scogings and Forster, 1989 and Scogings, 1992). It is bounded in the south by Halambu Granitoid Gness and by Woshane Amphibolites in the north (Germiquet, 1986). From north to south, the Bulls Run Syenite Complex shows extensive plastic deformation. Analyses of the potential ore of this complex are given in Table 1.

The chemical properties of the Bull's Run syenite make it also suitable for the glass and ceramics industry. Samples were submitted to several glass and ceramics manufacturers. There was positive response from the companies who stated that the material was suitable for their manufacturing processes. However, companies approached at the time would only consider using the material if its price was competitive with that of feldspar. An exploration programme was conducted to identify the area with highest potential. A cost study was also conducted. Although the financial parameters were positive, they were lower than what was normally desired for a new mining project at that time (Germiquet, 1986).

\section{The Red Syenite Deposit.}

The known surface exposure of the deposit on Zandrivierspoort is 7.8 hectares. A preliminary grid was designed at a line spacing of $50 \mathrm{~m}$ and a sample spacing of $50 \mathrm{~m}$. Not all intended sample positions could be sampled due to terrain difficulties. Thirty samples were collected. Composite samples were prepared and fifteen samples were submitted for $\mathrm{x}$-ray fluorescence (XRF) analysis. A petrographic study was also conducted on selected specimens. The following major elements were determined as oxides: $\mathrm{SiO}_{2}, \mathrm{Al}_{2} \mathrm{O}_{3}, \mathrm{Fe}_{2} \mathrm{O}_{3}, \mathrm{Na}_{2} \mathrm{O}, \mathrm{K}_{2} \mathrm{O}$, $\mathrm{CaO}, \mathrm{BaO}$ and $\mathrm{SrO}$, and in addition $\mathrm{F}$, total $\mathrm{Cl}$, and water soluble $\mathrm{Cl}$, and loss on ignition (L.O.I) were also analysed.

Specifications from selected glass and ceramics manufacturers were used to test the compliance of this material.
The aspects addressed are the following:

- The composition of the nepheline syenite of this deposit compared with the specifications from both ceramics and glass manufacturers

- Demand and potential demand for nepheline syenite

- The demand-supply trend in South Africa

- An analysis of the results of the market study

- An analysis of the effect of beneficiation on the price per ton as compared to selling raw material; and

- An analysis of the location of the deposit relative to that of the market and the effect of transport costs.

Unbeneficiated nepheline syenite rock samples from the current project were submitted to two companies that cannot be identified for confidentiality reasons, but here referred to as company A and company B. These companies tested the Red Syenite in their plants. Company $\mathrm{A}$ is a ceramic tiles manufacturer and $\mathrm{B}$ is a glass manufacturer. Other companies that were approached with a request for testing the material declined, by stating that they do not intend using nepheline syenite because of its scarcity, the perceived expenses attached to acquiring it, and perceived costs for plant conversions to work with an alternative source material.

After testing the raw nepheline syenite in its system Company A showed interest in the material. The material was deemed suitable for their use, and was actually similar to the material they are currently sourcing.

Company B, reported that the unbeneficiated material provided is not suitable for the glass they manufacture. The problem seemed to be a too high iron content in the raw material. Company B was also not willing to explore the option of beneficiating the material themselves.

From communicating with several other potential users, it was clear that most companies are not willing to substitute the raw material what they are using with nepheline syenite despite its advantages. There was also a general concern raised by potential users about the transport costs and the need for guarantees regarding the consistency in quality and supply. It is however expected that that these companies would be forced by a general scarcity of raw materials to consider an alternative source due to the large expansions in the industry.

\section{Petrography and chemical composition of the Red Syenite}

Table 3 shows the average composition obtained for the Red Syenite in this deposit. As can be seen from this table, the iron content of the raw material varies between 4.80 and 5.70 weight \% with a mean of 5.43 weight $\%$, comparing well with the iron content reported by Shand (1923). This is also comparable with the Bulls Run syenite, which varies between 4 and 8 weight $\%$. After test beneficiation, the iron content of the Red Syenite was reduced to an average of 0.81 weight $\%$, (Table 4) whereas the alumina content is upgraded to 
Table 1. Analyses of unbeneficiated Red Syenite samples from Zandrivierspoort

\begin{tabular}{|c|c|c|c|c|c|c|c|c|c|c|c|c|c|}
\hline Sample & SG & $\begin{array}{c}\mathrm{SiO}_{2} \\
\%\end{array}$ & $\begin{array}{c}\mathbf{A}_{2} \mathbf{O}_{23} \\
\% \\
\end{array}$ & $\begin{array}{c}\mathrm{Fe}_{2} \mathrm{O}_{3} \\
\% \\
\end{array}$ & $\begin{array}{c}\text { MgO } \\
\% \\
\end{array}$ & $\begin{array}{c}\mathrm{CaO} \\
\%\end{array}$ & $\begin{array}{c}\text { MnO } \\
\%\end{array}$ & $\begin{array}{l}\mathrm{P}_{2} \mathrm{O} 5 \\
\text { ppm }\end{array}$ & $\begin{array}{c}\mathrm{K}_{2} \mathrm{O} \\
\%\end{array}$ & $\begin{array}{c}\mathrm{Na}_{2} \mathrm{O} \\
\% \\
\end{array}$ & $\begin{array}{c}\text { Chloride } \\
\text { ppm }\end{array}$ & $\begin{array}{c}\text { Total S } \\
\% \\
\end{array}$ & $\begin{array}{c}\text { LOI } \\
\%\end{array}$ \\
\hline 001 & 2.67 & 58.20 & 14.85 & 4.95 & 0.71 & 1.24 & 0.28 & 1124 & 5.11 & 7.53 & 1547 & $\mathrm{~N} / \mathrm{D}$ & 1.16 \\
\hline 002 & 2.66 & 59.30 & 15.10 & 5.24 & 0.71 & 1.21 & 0.30 & 977 & 3.57 & 6.99 & 1387 & $\mathrm{~N} / \mathrm{D}$ & 1.22 \\
\hline 003 & 2.67 & 51.75 & 16.95 & 5.42 & 0.63 & 1.58 & 0.32 & 0.14 & 5.23 & 7.91 & 470 & $\mathrm{~N} / \mathrm{D}$ & 1.51 \\
\hline 004 & 2.68 & 52.60 & 15.70 & 5.31 & 0.61 & 1.22 & 0.31 & 0.26 & 5.17 & 7.72 & 512 & 0.013 & 1.82 \\
\hline 005 & 2.68 & 53.00 & 15.50 & 5.34 & 0.62 & 1.44 & 0.31 & 0.31 & 4.82 & 7.88 & 721 & 0.024 & 1.42 \\
\hline 006 & 2.69 & 53.40 & 15.40 & 5.38 & 0.69 & 1.55 & 0.27 & 0.18 & 4.83 & 6.85 & 664 & 0.019 & 1.77 \\
\hline 007 & 2.70 & 53.60 & 15.20 & 5.24 & 0.64 & 1.27 & 0.29 & 0.19 & 5.27 & 7.57 & 627 & 0.026 & 1.67 \\
\hline 008 & 2.68 & 54.80 & 15.90 & 5.63 & 0.62 & 1.30 & 0.30 & 0.19 & 5.43 & 7.80 & 520 & 0.010 & 1.61 \\
\hline 009 & 2.71 & 53.25 & 15.05 & 5.50 & 0.58 & 1.49 & 0.31 & 0.22 & 5.41 & 8.44 & 859 & 0.023 & 1.25 \\
\hline 010 & 2.72 & 55.10 & 16.10 & 5.05 & 0.63 & 1.27 & 0.29 & 871 & 4.73 & 7.59 & 0.16 & 0.029 & 1.22 \\
\hline 011 & 2.69 & 58.60 & 16.80 & 5.35 & 0.65 & 1.29 & 0.29 & 0.13 & 3.34 & 7.36 & 147 & 0.014 & 1.50 \\
\hline 012 & 2.69 & 50.60 & 13.80 & 4.98 & 0.66 & 1.33 & 0.29 & 0.14 & 4.29 & 7.74 & 175 & 0.014 & 1.63 \\
\hline 013 & 2.67 & 57.70 & 16.80 & 4.87 & 0.66 & 1.26 & 0.29 & 0.14 & 4.82 & 7.26 & 269 & 0.016 & 1.68 \\
\hline 014 & 2.69 & 56.90 & 16.30 & 5.35 & 0.72 & 1.63 & 0.32 & 644 & 4.77 & 7.91 & 548 & 0.010 & 1.98 \\
\hline 015 & 2.70 & 57.10 & 16.50 & 5.25 & 0.68 & 1.26 & 0.31 & 0.17 & 4.67 & 8.16 & 0.12 & $\mathrm{~N} / \mathrm{D}$ & 1.52 \\
\hline \multicolumn{14}{|l|}{ Number } \\
\hline of samples & 15 & 15 & 15 & 15 & 15 & 15 & 15 & 15 & 15 & 15 & 15 & 11 & 15 \\
\hline Mean & 2.69 & 55.06 & 15.73 & 5.26 & 0.65 & 1.36 & 0.30 & 241.17 & 4.76 & 7.65 & 563.05 & 0.02 & 1.53 \\
\hline Std. Dev. & 0.02 & 2.73 & 0.87 & 0.21 & 0.04 & 0.14 & 0.01 & 424.09 & 0.62 & 0.42 & 449.70 & 0.01 & 0.24 \\
\hline Minimum & 2.66 & 50.60 & 13.80 & 4.87 & 0.58 & 1.21 & 0.27 & 0.13 & 3.34 & 6.85 & 0.12 & 0.01 & 1.16 \\
\hline Maximum & 2.72 & 59.30 & 16.95 & 5.63 & 0.72 & 1.63 & 0.32 & 1124.00 & 5.43 & 8.44 & 1547.00 & 0.03 & 1.98 \\
\hline
\end{tabular}

over 20 weight $\%$. The minimum iron levels that may be practically achieved with magnetic separation in a beneficiation plant must be determined by bulk sample test work.

A petrographic study of the samples collected for this investigation reveals that $27 \%$ of these may be classified as foyaite. These samples most probably represent the gradational variety between the White Foyaite and the Red Syenite reported by Shand (1932). However, samples of the Red Syenite and those classified as foyaite contain on average 30 modal \% nepheline, which makes it a product of commercial interest. The fact that there are two rock types present in the deposit does raise some homogeneity concerns that should be addressed during a full feasibility investigation.

\section{Estimated resources, reserves and proposed production rate}

A total indicated resource of 10.2 million tons has been estimated. Dilution from other rock units is estimated to contribute 5 volume \% during quarrying. After mining the outcrop, a pit will be developed to a depth of $50 \mathrm{~m}$. It is estimated that approximately 10 volume \% oversize material will be rejected in the quarry. This brings the estimated probable reserve to $9.64 \mathrm{Mt}$. At a production rate for the product that varies between 750 and 1125 tons per day based on the present demand, the expected life of mine varies between 53 and 36 years. It is suggested to maintain a six months stockpile (approximately 10,000 t) to safeguard against unexpected interruptions in production and to ensure a homogenous plant feed. From these estimates it is clear that the deposit would be able to sustain production over a considerable period, but for pragmatic reasons a life of mine of ten production years are considered here (Smith, 1997).

Both ceramics and glass manufacturers indicated that the monthly consumption is approximately 1500 tons per month. The production rate per month is therefore based initially on the figure quoted by the ceramics manufacturers. It was also decided to base the production rate on the assumption of supplying only one of the two manufacturers.

\section{Cost structure of the proposed project}

A thorough investigation of the size of the deposit and its quality is of vital importance to evaluate its financial viability. It is believed that such an evaluation at this stage could only be done at a pre-feasibility level. For this purpose, a financial model is presented here based on the current market constraints. In the scenario investigated the raw material will be mined in an open cast operation and beneficiated to improve the product qualities, ensuring its adherence to compositional specifications and to prevent the transport of valueless materials.

The sensitivity of the project's financial criteria, such as the net present value (NPV), internal rate of return (IRR) and the payback period, to various risk factors will be addressed by referring to a discounted cash flow model of the project.

\section{Mining}

The mining method proposed is based on the following assumptions: 
- The material produced is suitable for ceramics manufacturing

- No preliminary stripping is required

- Total production sold per month is 1500 tons

- Quarry sorting is applied to 10 volume \% of blasted material

- Beneficiation will yield 75 volume $\%$ of product at a ceramics-grade specification; and

- The selling price is $\mathrm{R} 800 /$ ton for the beneficiated product.

The material will initially be obtained from a quarry where blasting will be required. Ten percent machine sorting will be conducted in the quarry and oversize blocks will be dumped as waste, while 90 volume $\%$ of the broken rock will be delivered to the beneficiation plant for further processing. Acquisition of this mining equipment will be funded by debt financing and will form part of the capital costs. After six years, machinery will be replaced and self-funded from the operating profit.

\section{Beneficiation}

The Run-Of-Mine (ROM) material will still be crushed, milled, and screened to obtain the required specification in the first stage of the processing of the ore. In the second stage, beneficiation takes the form of wet high-intensity magnetic separation, and drying. The magnetic fraction containing magnetite, ilmenite, sphene and entrapped nepheline is stockpiled to explore its potential future value. The non-magnetic product will be loaded and transported for a distance of about one hundred kilometres to a ceramics manufacturer.

\section{Rehabilitation programme}

Rehabilitation is considered an essential part of the planning process and an approved environmental impact assessment and rehabilitation management programme would be required before a mining licence would be granted. For the financial model, a rehabilitation fund will be established at R1.75 per ton (ROM). And the amount will be used as required during and after the mining activity has been completed to restore the land surface to the required norm.

Costs

Estimates for the mining and beneficiation costs considered are provided and motivated in Pantshi (2006) and may be summarised as:

Capital Costs

R10.2 (million)

Operating costs

Production $\left(R 7.00 / \mathrm{m}^{3}\right)$

R2.69/ton ore

Processing

Transport

R3.60/ton ore

Rehabilitation fund contributions

Salaries and Labour per month

$\mathrm{R} 1.10 / \mathrm{ton} / \mathrm{km}$

$\mathrm{R} 1.75 /$ ton

$\mathrm{R} 270$ 000/m.

\section{Financial evaluation of the proposed project}

A study on the financial viability of the deposit needs to consider the costs of production, commodity price, capital required and the production rate. Most importantly an undeveloped deposit must be assessed for its "place value". This is a problem in South Africa, as most deposits are located far away from the market, which in this case is located in the Gauteng Province. The "place value" includes transportation costs to the market, the nature of markets, the specific product demand, the capital and production costs.

In South Africa, the current price per ton for nepheline syenite varies between R350 and R500 depending on quality of the unbeneficiated material and about R800 for beneficiated material. Production costs generally include drilling and blasting of the material to a coarser size, and this material is later crushed and milled to the size required by the client. Most companies, more especially ceramics producers, consume an average of 1500 tons per month of nepheline syenite at a grain size of less than $10 \mathrm{~mm}$. Costs that are reflected in a cash flow model are associated with developing, mining, and processing of the material

The financial evaluation of this project is undertaken on the basis of the intention to mine the deposit where the internal rate of return (IRR) and net present value (NVP) are important financial criteria for the fair

Table 2. Comparison of beneficiated nepheline syenite from various deposits.

\begin{tabular}{|c|c|c|c|c|c|c|}
\hline $\begin{array}{l}\text { Chemical } \\
\text { Composition }\end{array}$ & $\begin{array}{l}\text { Pilandesburg } \\
\text { Red Syenite }^{1}\end{array}$ & Bulls Run ${ }^{2}$ & Canada $^{3}$ & Norway $^{3}$ & $\begin{array}{c}\text { United States of America } \\
\text { Maine Litchfield }^{3}\end{array}$ & Congo $^{3}$ \\
\hline $\mathrm{SiO}_{2}$ & 56.82 & 52.61 & 58.80 & 52.37 & 60.39 & 55.44 \\
\hline $\mathrm{Al}_{2} \mathrm{O}_{3}$ & 22.56 & 23.86 & 23.00 & 23.22 & 22.51 & 23.59 \\
\hline $\mathrm{Fe}_{2} \mathrm{O}_{3}$ & 0.81 & 0.22 & 0.80 & 1.10 & 0.42 & 0.44 \\
\hline $\mathrm{MgO}$ & 0.70 & 0.11 & 0.04 & 0.25 & 0.13 & 0.14 \\
\hline $\mathrm{CaO}$ & 1.44 & 1.19 & 0.82 & 3.11 & 0.32 & 1.56 \\
\hline $\mathrm{MnO}$ & 0.29 & 0.02 & 0.05 & 0.09 & 0.08 & 0.15 \\
\hline $\mathrm{P}_{2} \mathrm{O}_{5}$ & 0.19 & 0.32 & 0.01 & 0.09 & - & 0.18 \\
\hline $\mathrm{K}_{2} \mathrm{O}$ & 5.01 & 6.92 & 5.20 & 8.30 & 4.77 & 6.26 \\
\hline $\mathrm{Na}_{2} \mathrm{O}$ & 8.92 uiop & 8.53 & 9.40 & 6.87 & 8.44 & 10.20 \\
\hline LOI & 1.59 & 1.30 & - & - & - & 1.62 \\
\hline Total & 98.33 & 95.08 & 98.12 & 95.40 & 97.06 & 99.58 \\
\hline
\end{tabular}


value estimation. Financial parameters that will be applied within the discounted cash flow model (DCFM) for the base case are the following:

$\begin{array}{ll}\text { Inflation rate } & 4 \% \\ \text { Discount rate } & 14 \% \\ \text { Interest rate } & 12 \% \\ \text { Royalty } & 1 \% \\ \text { Tax rate } & 29 \% .\end{array}$

\section{The discounted cash flow model}

A simplistic, Microsoft Excel discounted cash flow model (DCFM) was used to assess the financial viability of the project. The inputs and outcomes of the project evaluation are discussed below.

At a selling price of R800, gross revenue generated from producing 16200 tons is R13.5 million. Royalties on gross revenue will be payable to the government at the proposed rate 1 weight $\%$. This is based on the assumption that the Mining Royalty Bill will be in place by time production commences. It is expected that the annual operating cost will be about R90 000 for the first year of full production (year two of the project). The operation is expected to repay the capital loan in year three of the project. Quoted transport costs are $\mathrm{R} 1.10 /$ ton per $\mathrm{km}$, bringing the annual costs for transportation to an estimated R1.8 million in the first year of full production.

Capital outlay required has been estimated at R10.2 million. It is assumed that the project will be debt financed with repayment starting at the end of the first full year of production Capital expenditure incurred will be for the establishing the necessary infrastructure, mining machinery, plant infrastructure, office buildings, overheads, interest, and the mining of the stockpile. A discount rate of $14 \%$ for the base case was selected based on the sum of the current bond rate of about $8 \%$, and an estimated project risk rate of $6 \%$. An appropriate hurdle rate for this projects estimated internal rate of return (IRR) may be set at $24 \%$, which is two times the cost of capital. Using this hurdle rate it becomes evident that the production should not be less than 16,000 tons per year and for this reason the planned production rate is set at 16,200 tons per year requiring a run of mine rate of 24,000 tons per year. Over a life of mine period of 11 years, with full scale mining having commenced in year two the outcomes of the discounted cash flow model are:

$N P V$

IRR

Payback period (Months)

Maximum cash exposure

$\begin{array}{ll}= & \text { R10.76 million } \\ = & 29 \% \\ = & 17 \\ = & -R 11.4 \text { million }\end{array}$

The NPV of the project is positive and the IRR indicates that the return generated by the project will exceed the hurdle rate set above. At a production rate of 16200 tons sales per annum, the debt will be paid back in 17 months (Figure 3).

\section{Risk related to the project:}

The risks for such a project to fail may be investigated using two methods namely sensitivity or risk analysis (Rudenno, 1998). In the first, the financial outcomes of the project are tested by successively varying the input parameters in a systematic manner. This method normally results in an effective identification and prioritisation of the most important risk factors and guide steps that may then be taken to ameliorate the risk in the future outcome of the project, as used by Minnaar and Theart (2007). The method however remains simplistic, as it does not consider the simultaneous or

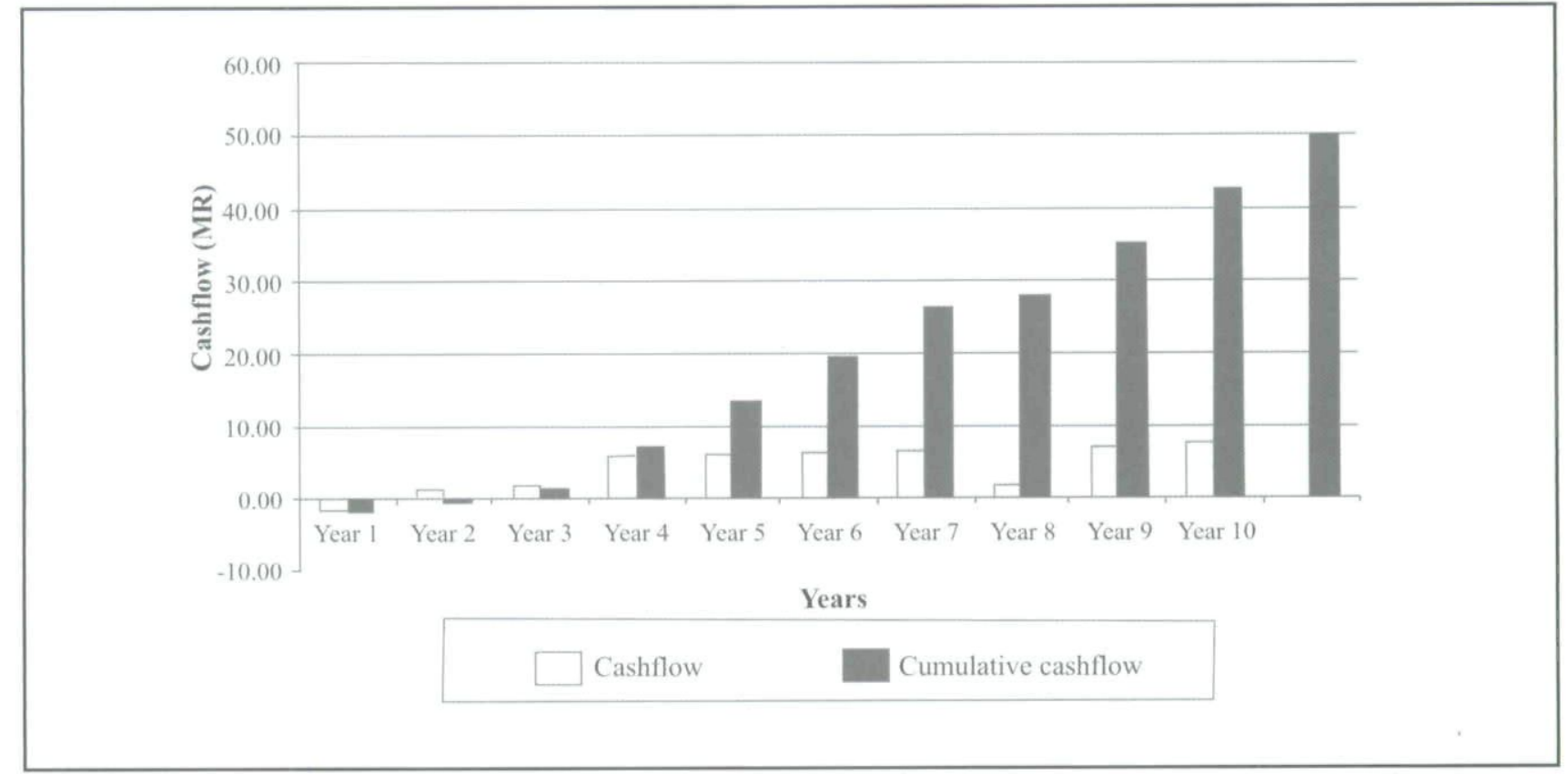

Figure 3. Cash flow diagram for beneficiated product of the Red Syenite from Zandrivierspoort. 

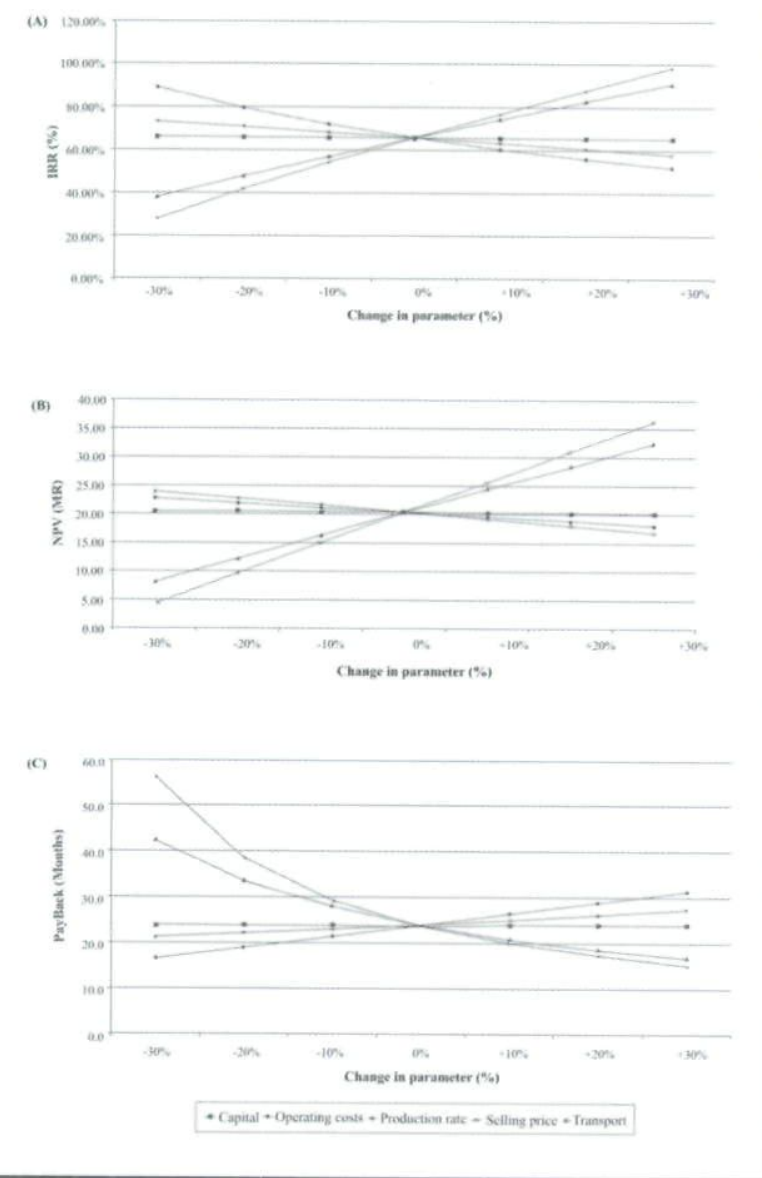

Figure 4. The Red Syenite Project's sensitivity to variations in capital costs, operating costs, production rate, selling price, and transport costs relative to the project's IRR (A), NPV (B) and payback period $(\mathbf{C})$.

combined effect of all the various risks at any one time. In order to achieve the latter the input parameters are allowed to vary simultaneously, but within a wellconstrained range, representing the best estimate of the parameter's variability. The project's risk may then be considered using a statistical interpretation of the population of values for any of the financial outcomes of the discounted cash flow model.

\section{Sensitivity analysis:}

The results of a sensitivity analysis testing the effect of a number of on the NPV, IRR, and payback period for this scenario are presented below: In this case, parameters that are changed systematically include:

- Capital expenditure (Capex)

- Operating costs

- Production rate

- Selling price per ton (selling price)

- Transport costs.

The effect these variations have on the IRR, NPV, and payback period are listed in Table 6. The base parameters were changed by up to $-30 \%$ to $30 \%$ and the effect in financial variables may be seen graphically in
Figure 4 . Table 6 shows what the IRR, NPV, and payback will be when various changes are applied. For example, in the first table an $89 \%$ IRR is obtained when capital is reduced by $30 \%$. When looking at the effect of a change in transport costs, a $30 \%$ increase in transport costs will decrease the IRR to $58 \%$.

From Figure 4, it is observed that capital, production rate, and selling price have a higher influence on the IRR than other parameters do. The IRR increases with the reduction in capital and is reduced when the selling price is reduced. Transport and operating costs have the smallest effect on the IRR. The production rate and selling price have the highest influence on the NPV obtained. The selling price needs to decrease by approximately $35 \%$ before the NPV becomes negative. From the figure it is observed that capital, operating, and transport costs have the smallest influence on the NPV. However, a combination of these parameters could have a significant negative effect on the project.

It is evident that the production rate and the selling price have a major influence on how long it will take to pay back the debt. A 30\% reduction in the selling price might increase the payback period to 56 months (Figure 4). Capital, operating and transport costs have a minimum influence on the payback time. A stable price and a constant or increasing demand of the product will keep the project healthy and payable in two years. A reduction in the capital outlay will also obviously reduce the payback term, assuming production rate does not decrease.

From the sensitivity analysis it is concluded that the project is most sensitive to changes in capital, production rate and the selling price.

\section{Risk analysis:}

In a risk analysis of this project, simultaneous variability in parameters such as the amount of ore mined in order to maintain a consistent product production, the amount of oversize reject, product recovery, unit costs for mining and processing, transport costs, selling price, tax and the inflation rates are considered. The variability of these parameters was modelled by defining the population that best describe the potential variability. The most important conditions for this are to avoid logical correlations between some of the parameters, and double accounting. Although there is a correlation between operational costs and the inflation rate, it was decided to include the variability in this parameter only at the beginning of the project whereas the inflation rate is allowed to vary throughout the project's life. All of the other parameters display a strong independence in their values at the beginning of operation. The most common source of double accounting is in allowing for a discount rate in the model, which is already accounting for some of the project risk that is now also expressed in the variability of the other parameters. However, it is important to note that the project's risk can also not be lower than the country's risk that is reflected in the bond rate. Table 4 lists the parameters and gives 
Table 3. Results of a sensitivity analysis.

\begin{tabular}{|c|c|c|c|c|c|}
\hline \multicolumn{6}{|c|}{ IRR Variations (\%) } \\
\hline$\%$ Change & Capital & Operating Costs & Production rate & Transport & Selling Price \\
\hline$-30 \%$ & $76.03 \%$ & $57.46 \%$ & $28.13 \%$ & $65.93 \%$ & $15.31 \%$ \\
\hline$-20 \%$ & $68.49 \%$ & $57.37 \%$ & $38.57 \%$ & $63.05 \%$ & $31.41 \%$ \\
\hline$-10 \%$ & $62.34 \%$ & $57.29 \%$ & $48.14 \%$ & $60.14 \%$ & $44.87 \%$ \\
\hline $0 \%$ & $57.20 \%$ & $57.20 \%$ & $57.20 \%$ & $57.20 \%$ & $57.20 \%$ \\
\hline$+10 \%$ & $52.82 \%$ & $57.12 \%$ & $65.93 \%$ & $54.23 \%$ & $68.93 \%$ \\
\hline$+20 \%$ & $49.04 \%$ & $57.03 \%$ & $74.45 \%$ & $51.21 \%$ & $80.29 \%$ \\
\hline$+30 \%$ & $45.73 \%$ & $56.95 \%$ & $83.55 \%$ & $48.15 \%$ & $91.42 \%$ \\
\hline \multicolumn{6}{|c|}{ NPV Variations (MR) } \\
\hline$\%$ Change & Capital & Operating Costs & Production rate & Transport & Selling Price \\
\hline$-30 \%$ & 10.29 & 9.27 & 2.54 & 11.43 & 0.21 \\
\hline$-20 \%$ & 9.93 & 9.25 & 4.76 & 10.69 & 3.21 \\
\hline$-10 \%$ & 9.57 & 9.23 & 6.98 & 9.95 & 6.21 \\
\hline $0 \%$ & 9.21 & 9.21 & 9.21 & 9.21 & 9.21 \\
\hline$+10 \%$ & 8.85 & 9.19 & 11.43 & 8.47 & 12.21 \\
\hline$+20 \%$ & 8.49 & 9.17 & 13.66 & 7.73 & 15.21 \\
\hline$+30 \%$ & 8.12 & 9.15 & 15.95 & 6.99 & 18.21 \\
\hline \multicolumn{6}{|c|}{ Payback Variations (Months) } \\
\hline$\%$ Change & Capital & Operating Costs $\quad \operatorname{Pr}$ & tion rate & Transport & Selling Price \\
\hline$-30 \%$ & 17.9 & 25.4 & 50.7 & 21.9 & 77.4 \\
\hline$-20 \%$ & 20.4 & 25.4 & 38.1 & 23.0 & 46.1 \\
\hline$-10 \%$ & 23.0 & 25.5 & 30.6 & 24.2 & 32.8 \\
\hline $0 \%$ & 25.5 & 25.5 & 25.5 & 25.5 & 25.5 \\
\hline$+10 \%$ & 28.0 & 25.5 & 21.9 & 27.0 & 20.8 \\
\hline$+20 \%$ & 30.5 & 25.6 & 19.2 & 28.7 & 17.6 \\
\hline$+30 \%$ & 33.0 & 25.6 & 17.8 & 30.6 & 15.3 \\
\hline
\end{tabular}

a short description of the variability allowed in the model.

These parameters are allowed to be sampled in a random manner (given that they vary within the predetermined manner and then fed into the discounted cash flow model. The model's output values will then form a population that could be interpreted statistically to indicate the projects likelihood to succeed. Various software packages such as @RISK, Crystall Ball may be used to generate the simulations in this case Decision Support's Risksim application within Microsoft Excel was used to calculate the trials. The software was set to calculate output values for 1000 trials with a seed number of 0.5 . The frequency distribution of the NPV values generated is given in Figure 5.

From the statistics provided, and given the assumptions used in the definition of the likely distributions of the different input parameters in the discounted cash flow model, it could be seen that the project has a very small likelihood of failure, where the NPV would be less than 0 (less than 5\%). Furthermore, the mean IRR value far exceeds the hurdle rate of $24 \%$ set above

\section{Conclusions}

The Pilanesberg Red Syenite and the Bulls Run syenite have higher percentages of nepheline as compared to other nepheline-bearing deposits worldwide. It is strongly recommended that more work be done on the delineation of the Red Syenite as it was found that some of the samples collected for this investigation may be classified white foyaite. It needs to be demonstrated that contamination by such material would not adversely affect the product. This will ensure that long-term contracts may be based on the correct geological data and resources and reserves are quantified accurately to allay concerns maintaining of the same quality supplies over the longer period.

Samples submitted to glass and ceramics manufacturers triggered an interest in the use of nepheline syenite in ceramics. During feasibility studies it is important that both beneficiated and unbeneficiated samples need to be distributed for process testing. The deposit's composition complies with the specifications of ceramics manufacturers. The glass manufacturer through its testing procedure established that the unbeneficiated product did not comply with the production of the kind of glass produced. Major limitations on nepheline syenite being the preferable raw material for these industries are the availability and abundance of competing substitutes such as feldspar. Despite nepheline syenite having obvious advantages over substitutes, inertia to change in the market is great.

From the DCF, it has been established that the project remains viable even at a discount rate of $18 \%$ for both the beneficiated and unbeneficiated product. The project is most sensitive to changes in capital requirements, 
Table 4. Input parameter variation allowed in a DCFM used in a risk analyses of the Red Syenite Project.

\begin{tabular}{|c|c|}
\hline Parameter & Definition of associated population \\
\hline Run Of Mine Production ( $\mathrm{t} /$ year) & Regarded as a normal population with a mean of $24000 t$ and a standard deviation of $2400 \mathrm{t}(10 \%)$ \\
\hline Oversize reject (\%) & $\begin{array}{l}\text { Oversize reject is regarded as a normal distribution with } 10 \% \text { as the mean and a standard deviation } \\
\text { of } 0.5 \%(5 \%)\end{array}$ \\
\hline Product Recovery (\%) & $\begin{array}{l}\text { Percentage recovery is regarded as a normal population with a mean of } 75 \% \text { and a standard } \\
\text { deviation of } 3.75 \%\end{array}$ \\
\hline Unit cost for mining $(\mathrm{R} / \mathrm{t})$ & $\begin{array}{l}\text { The unit cost for mining is regarded a triangular distribution with a minimum of } \mathrm{R} 2.42(10 \%) \text {, a most } \\
\text { likely of R2.69 and a maximum of R3.23. }\end{array}$ \\
\hline Unit cost for processing $(\mathrm{R} / \mathrm{t})$ & $\begin{array}{l}\text { The unit cost for processing is regarded a triangular distribution with a minimum of } \mathrm{R} 3.42(5 \%) \text {, a } \\
\text { most likely of } \mathrm{R} 3.6 \text { and a maximum of } \mathrm{R} 3.78(5 \%) \text {. }\end{array}$ \\
\hline Transport costs $(\mathrm{R} / \mathrm{t} / \mathrm{km})$. & $\begin{array}{l}\text { Transport costs are regarded a triangular distribution with a minimum of R1.10, a most likely of } \\
\mathrm{R} 1.20 \text { and a maximum of } \mathrm{R} 1.44(+20 \%) \text {. }\end{array}$ \\
\hline Selling price $(\mathrm{R} / \mathrm{t})$. & $\begin{array}{l}\text { Selling price is regarded as a normal distribution with a mean of } \mathrm{R} 800 \text { and a standard deviation of } \\
\mathrm{R} 80(10 \%) \text {. }\end{array}$ \\
\hline Inflation (\%). & $\begin{array}{l}\text { Inflation is regarded as a triangular distribution with a minimum of } 4 \% \text { a, most likely of } 5 \% \text {, and a } \\
\text { maximum } 10 \% \text {. }\end{array}$ \\
\hline Tax rate $(\%)$ & $\begin{array}{l}\text { Tax rate is regarded as a triangular distribution with } 28 \% \text { as a minimum, } 29 \% \text { as a most likely, and } \\
32 \% \text { as maximum. }\end{array}$ \\
\hline
\end{tabular}

production rate and selling price. An increase in both the production rate and the selling price will have a positive outcome on the IRR, NPV and the payback period. A decline in the demand, which will be reflected by the decline in the production rate, will reduce the IRR and NPV significantly. Transport and operating costs have a small effect viability of the project; however, the combination of these parameters can have a significant effect on the viability of the project.

Two scenarios were considered during this investigation namely the production of beneficiated and unbeneficiated product aimed at the glass and ceramics industry, although only the first are presented here. Both scenarios have shown to be financially viable and robust in terms of the input parameters tested in sensitivity analyses (Table 5).

From the comparison it could be concluded that the only aspect in favour of scenario 2 is the fact that the maximum cash flow exposure is $34 \%$ less than in

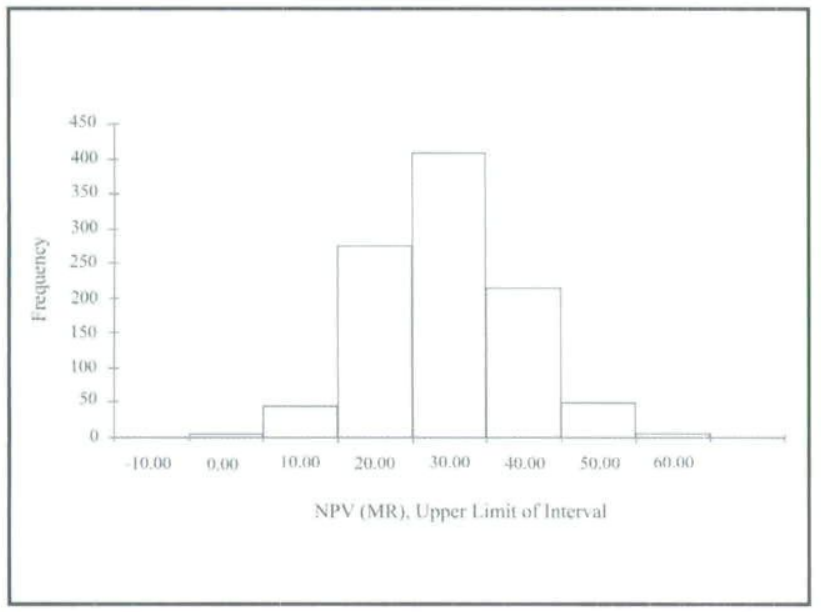

Figure 5. A frequency distribution of the population of NPV values (million Rand) obtained from a risk analysis of the Red Syenite Project. scenario 1 . This is however overshadowed by the additional shareholder value offered by scenario 1 . Of greater importance is the other aspects not considered in the DCF model.

- Scenario 2 is dependent on a single buyer of its product. This could however be negated by longterm off-take agreements and possible sharing in financial risk. Scenario 2 is also more sensitive to a drop in commodity price than scenario 2 .

- Scenario 1 may only be successful if the barriers in the South African glass manufacturing industry can be overcome and nepheline syenite is accepted as a replacement of feldspar. This could come about if the feldspar producers could not cope with the demands of the growing industry. Scenario 1 is clearly less sensitive to adverse conditions and should be seen as the preferred option for long-term.

It is recommended that a hybrid scenario be considered where the first phase of the project resemble scenario 2 and the second phase which would be self funded an expansion of the project to include the beneficiation plant envisaged in scenario 1. The second phase would be triggered once the operation has proven itself in terms of its ability to produce a homogeneous product consistently and adequate pilot plant tests were done to justify the glass manufacturers to convert capacity or create new capacity based on nepheline syenite raw material.

Table 5. Comparison of the two scenarios investigated (discount rate $14 \%$ )

\begin{tabular}{lll}
\hline Financial criterionI & Scenario 1 & Scenario 2 \\
\hline NPV & R20.30 million & R 9.21 million \\
IRR & $66 \%$ & $57 \%$ \\
Pay back period & 23.8 & 25.5 \\
Maximum cash exposure & R1.66 million & R1.10 million \\
\hline
\end{tabular}




\section{Acknowledgements}

The authors are grateful to Randgold and Exploration Limited for giving the first author an opportunity to investigate The Bull's Run nepheline syenite deposit that eventually led to selecting the Pilanesberg Red Syenite as project for her MSc (ESPM) degree. We specifically whish to thank Mr Rob Lindsay (Technical Manager Randgold and Exploration Limited) for his introduction of the first author to the topic and for his encouragement. The helpful comments of the referees John Polasek and Peter Ringdahl are greatfully acknowledged.

\section{References}

Agnello, V.N., Mokaila, G.E. and Ratlabala, M.E. (2003). Statistics for other industrial minerals. In: South Africa's Mineral Industry (2002/2003), 164

Agnello, V.N., Mokaila, G.E. and Naidoo, D. (2004). Statistics for other industrial minerals. In: South Africa's Mineral Industry (2003/2004). 196-197.

Boelema, R. (1998). Feldspar In: M.G.C. Wilson and C.R. Anhaeusser (Editors), The Mineral Resources of South Africa Wilson, Handbook of the Council for Geoscience, 16, 267-268.

Cawthorn, R.G. (2001). Platinum and other deposits of the Bushveld Complex, South Africa, and comparisons with occurrences worldwide. Department of Geology and Geophysics, the University of Australia. p2.

Cuillo, P.A. and Robinson, S. (2003). Feldspar and Nepheline Syenite Fillers with a Purpose. Painting and Coating Industry. Retrieved on the 14 March 2005 from the World Wide Web:http://www.pcimag.com/CDA/ ArticleInformation/features/. 10 January 2003.

Daly, M.J. (1990). Bull's Run Nepheline Syenite application for mining lease: Portion of farm Goedertrouw 7806, Mthonjaneni district, KwaZulu. Mining Department Internal Report. South African Development Trust Corporation Limited.

Germiquet, J.D. (1986). Research Investigation into the nepheline syenite potential of the Bull's Run Syenite Complex, KwaZulu. Mining Department Internal Report. South African Development Trust Corporation Limited. July 1986.

Horn G.F.J. (1994). Optimizing the exploration for and the exploitation of industrial mineral resources. Fifteenth CMMI Congress, South African Institute of Mining and Metallurgy, 3, 215-224.

Humphrey, A.W. (1914). The geology of the Pilandsberg and the surrounding country. Union of South Africa, Mines Department, Geology Survey. Report of the Geological Survey of South Africa, 1911(3), 75pp.
Lurie, J. (1986), Mineralization of the Pilanesberg Alkaline Complex. 22152228. In: R. Anhaeusser and S. Maske (Editors). Mineral Deposits of Southern Africa. Geological Society of South Africa. 2215-2227.

Minnaar H., and Theart H.F.J. (2006). The exploitability of pegmatite deposits in the lower Orange River area (Vioolsdrf - Henkries - Steinkopf). South African Journal of Geology. 109, 341-352.

Minnes, D.G. (1975). Nepheline Syenite. Industrial Minerals and Rocks. 4th Edition, Lefond, 861-894.

Mintek chemical analysis reports, 2004 .

Molengraaff G.A.F. (1901). Geologie de la Republique Sud-Africaine du Transvaal. Geological Society of France, 92pp.

Pantshi B. (2006). The red syenite of the Pilanesberg Complex as a nepheline source for the South African ceramics and glass industry. Unpublisbed M.Sc. Treatise (Eartb Science Practce and Management), University of Pretoria, South Africa, 68pp.

Retief, E.A. (1963). Petrological and mineralogical studies in the southern part of the Pilanesberg Alkaline Complex, Transvaal, South Africa. Unpublished Ph.D. thesis, Oxford University, United Kingdom, 260pp.

Rudenno, V. (1998). The Mining Valuation Handbook. Wrightbooks (Pty) Limited, Elstenuck, Victoria, Australia, 247p

Schürman, L.W. Grabe, P.J. and Steenkamp, C.J. (1998). Chromium in: M.G.C. Wilson and C.R. Anhaeusser (Editors), The Mineral Resources of South Africa Wilson, Handbook of the Council for Geoscience, 16, 90-105.

Scogings, A.J. (1992). The Bull's Run Syenite Complex, Natal. (Extended Abstract of paper presented at the Bloemfontein Geocongress). South African Development Trust Corporation Limited. November 1992.

Scogings, A.J. and Forster, I.F. (1989). Gneissose Carbonatites in the Bull's Run Complex, Natal. South African Journal of Geology, 92, 1-10.

Shand, S.J. (1932), The geology of Pilansberg (Pilaansberg) in the Western Transvaal: A study of Alkaline Rocks and Ring intrusions. Transaction Geological Society South Africa, 31, 97-156.

Smith, D.L. (1997). Mineral Economics: A critical examination of the methods and factors affecting selection of an optimum production rate. Canadian Institute of Metallurgy Bulletin. 90, 48-54.

Spectrum Canadian Nepheline Syenite. Technical Data. Retrieved on the 14 March 2005 from the World Wide Web: hup:// www.trinityceramics.com. SACS (South African Committee for Stratigraphy), (1980), Stratigraphy of South Africa. Part 1 (Comp. L.E. Kent). Lithostratigraphy of the Republic of South Africa, South West Africa/Namibia, and the Republics of Boputhatswana, Transkei and Venda: Handbook of the Geological Survey of South Africa, 8, 401.

Viljoen M.J. and Schürman, L.W. (1998). Platinum-Group Metals In: M.G.C. Wilson and C.R. Anhaeusser (Editors), The Mineral Resources of South Africa. Handbook of the Council for Geoscience, 16, 532-568.

Editorial handling: J.M. Barton 
Copyright of South African Journal of Geology is the property of Geological Society of South Africa and its content may not be copied or emailed to multiple sites or posted to a listserv without the copyright holder's express written permission. However, users may print, download, or email articles for individual use. 